\title{
Outcome of vaginal sildinafil in assisted reproductive technology cycles
}

\author{
Avnika Kapoor *, Garima Sharma, Rita Bakshi
}

International Institute of Reproductive and Fertility Centre (IIRFT), Green Park, New Delhi, India

Received: 19 November 2020

Accepted: 04 January 2021

\section{*Correspondence:}

Dr. Avnika Kapoor,

E-mail: avnika_kapoor@yahoo.co.in

Copyright: (c) the author(s), publisher and licensee Medip Academy. This is an open-access article distributed under the terms of the Creative Commons Attribution Non-Commercial License, which permits unrestricted non-commercial use, distribution, and reproduction in any medium, provided the original work is properly cited.

\section{ABSTRACT}

Background: The present study assessed the role of sildenafil in endometrial blood flow and successful pregnancy in IVF done in surrogate mothers.

Methods: In the present study surrogate mothers were included. Thirty patients were randomized to receive sildenafil $25 \mathrm{mg}$ thrice a day vaginally in addition to standard drugs and technique and another 30 were not given sildenafil.

Results: Mean age, anthropometry, duration of infertility and pre-treatment endometrial thickness was similar in the two study groups. After treatment completion, it was observed that the endometrial pattern in ultrasound was similar in the two study groups ( $p$ value $=0.58$ ). Heterogenic endometrial pattern was observed in $6.7 \%$ of the Sildenafil patients and $3.3 \%$ in the control patients, while echogenic pattern was seen in $10 \%$ of the sildenafil patients and $6.7 \%$ of the control patients. Similarly, endometrial thickness was $10.2 \pm 1.7$ and $9.7 \pm 1.8 \mathrm{~mm}$ in sildenafil and control group respectively, $\mathrm{p}$ value $=0.62$. Using doppler ultrasound, uterine artery PI was significantly lower in Sildenafil group patients as compared to control group patients. Similarly, we found uterine artery RI was also significantly lower in the Sildenafil group patients as compared to control group patients. We followed the patients and found that clinical pregnancy rate was significantly higher among Sildenafil group (60\%) as compared to control group (26.6\%), p value $<0.05$.

Conclusions: Vaginal sildenafil resulted in significantly higher pregnancy rates in our study population. The uterine artery PI and RI were significantly lower in patients taking sildenafil.

Keywords: Outcome, Sildenafil citrate

\section{INTRODUCTION}

Successful implantation of an embryo requires an endometrium which is receptive, an embryo of good quality and synchronization of embryo and endometrium. ${ }^{1}$ Sildenafil citrate is a 5-phosphodiestrase inhibitor that increases smooth muscle relaxation and vasodilation by preventing cGMP breakdown. Sildenafil citrate increases blood flow in the uterine artery and, results in estrogen- induced proliferation of the endometrium when in presence of estrogen. ${ }^{2}$ It has believed that sildenafil when given vaginally significantly decreases peripheral natural killer cell (NK-cell) activity and improves successful pregnancy rates in women with histories of recurrent miscarriages. Several studies have been conducted trying to generate evidence about the effectiveness of sildenafil citrate on the outcomes of ART. However, no definitive conclusion has been established and the issue is still debatable. ${ }^{3}$ The present study was conducted to assess the role of sildenafil in endometrial proliferation in patients with failed in vitro fertilization/intracytoplasmic sperm injection (IVF/ICSI) attempts.

\section{METHODS}

The present prospective, randomized study was conducted in International Institute of Reproduction and 
Fertility Training (IIRFT) New Delhi. Patients were explained the purpose of the study and an informed written consent was obtained. The study was approved by the IIRFT Head and faculty. From June 2020 till August 2020, we included surrogates who are part of surrogacy program running in the centre. Procedure of embryo transfer was only done in them after preparing their uterine endometrial lining. Oocyte retrieval were not done on them. So they were called during menstrual cycle and started with treatment for only embryo transfer. Two study groups were made: Group I was Sildenafil group, in which patients were given $25 \mathrm{mg}$ thrice a day vaginally in addition to standard drugs and technique for ICSI and Group II was control group, who did not receive Sildenafil but only standard drugs and technique. Inclusion criteria included surrogate mothers of 18 to 35 years of age, normal uterine anatomy on transvaginal ultrasound and regular menstrual history. We excluded patients with severe hepatic, renal or cardiorespiratory disease. Sample size was calculated by formula $n=$ $\left(\mathrm{Z}_{\alpha / 2}+\mathrm{Z}_{\beta}\right) \times \mathrm{PQ} * 2 / \mathrm{d}^{2}$, where $\mathrm{P}=$ average proportion of a variable, $\mathrm{Q}=1-\mathrm{P}, \mathrm{Z}_{\alpha / 2}$ is type I error at $1 \%(2.56)$ and $\mathrm{Z} \beta$ is type II error at $5 \%(1.64), \mathrm{d}$ is allowable error $(0.3)$. Yahia et al reported clinical pregnancy rate of $51.4 \%$ in Sildenafil group and $20 \%$ in control group. So $\mathrm{P}=$ $(0.514+0.84) / 2=0.35$. So sample size was calculated as 22 in each group. Considering expected attrition, we included 30 patients in each study group.

\section{Data collection and data analysis}

After informed consent, all the patients included received vaginal dose of $25 \mathrm{mg}$ of Sildenafil citrate three time daily to day $21 \mathrm{st}$ of same cycle after receiving other medications like estrogen, antibiotics, folic acid and ecospirin supplements. Demographic, obstetrical and anthropometric measurements were noted for all patients. Transvaginal ultrasound (TVS) was conducted to detect endometrial thickness and uterine artery blood flow Doppler was done. Pulsatility index (PI) was calculated as the difference between the peak systolic and enddiastolic velocities divided by the mean velocity during the cardiac cycle, which is a measure of the variability of blood velocity in the uterine artery. Resistance index was calculated as the difference between the peak systolic and end-diastolic velocities divided by the peak systolic velocity, which is an indicator of the resistance of uterine artery to perfusion. Outcome measures was pregnancy rate, endometrial thickness and uterine artery blood flow on doppler. A clinical pregnancy was confirmed by ultrasonography visualization of one or more gestational sacs or definitive clinical signs of pregnancy.

Data were analysed in SPSS version 23 (IBM, New York). Descriptive analysis was performed for quantitative data (means and standard deviation) and qualitative data (proportions). Quantitative data were compared between the two study groups using student's t test and chi-square was used to compare qualitative data.
A p value less than 0.05 was considered as statistically significant.

\section{RESULTS}

During the study period, 30 patients were included in each study group. Mean age of the patients was 32.5 and 31.7 years in the study groups, $p$-value $=0.76$. Anthropometric measures like heights, weight and BMI were also similar in the patients in the two study groups. Before start of the treatment, mean endometrial thickness was $8.01 \pm 1.7$ and $8.5 \pm 1.9 \mathrm{~mm}$ in the sildenafil group and in the control group respectively, p-value $=0.51$. After treatment completion, it was observed that the endometrial pattern in ultrasound was similar in the two study groups ( $\mathrm{p}$-value $=0.58)$.

Table 1: Baseline characteristics of the patients included in the two study groups.

\begin{tabular}{|llll|}
\hline $\begin{array}{l}\text { Baseline } \\
\text { characteristics } \\
\text { of the patients }\end{array}$ & $\begin{array}{l}\text { Sildenafil } \\
\text { group } \\
(\mathbf{n = 3 0})\end{array}$ & $\begin{array}{l}\text { Control } \\
\text { group } \\
(\mathbf{n = 3 0})\end{array}$ & $\begin{array}{l}\mathbf{P} \text { - } \\
\text { value }\end{array}$ \\
\hline $\begin{array}{l}\text { Mean age } \\
\text { (years) }\end{array}$ & $32.5 \pm 7.3$ & $31.7 \pm 8.18$ & 0.76 \\
\hline Weight (kg) & $66.54 \pm 10.93$ & $64.75 \pm 11.05$ & 0.47 \\
\hline Height (cm) & $154.4 \pm 8.33$ & $156.37 \pm 9.15$ & 0.36 \\
\hline $\begin{array}{l}\text { Body Mass } \\
\left.\text { Index (kg/m } \mathbf{m}^{\mathbf{2}}\right)\end{array}$ & $28.56 \pm 4.3$ & $27.64 \pm 4.9$ & 0.18 \\
\hline $\begin{array}{l}\text { Infertility } \\
\text { duration (years) }\end{array}$ & $4.5 \pm 1.7$ & $4.9 \pm 1.2$ & 0.08 \\
\hline $\begin{array}{l}\text { Endometrial } \\
\text { thickness (mm) }\end{array}$ & $8.01 \pm 1.7$ & $8.5 \pm 1.9$ & 0.51 \\
\hline
\end{tabular}

Table 2: Comparing outcomes in the Sildenafil and control group after treatment.

\begin{tabular}{|c|c|c|c|}
\hline $\begin{array}{l}\text { Outcome } \\
\text { variables }\end{array}$ & $\begin{array}{l}\text { Sildenafil } \\
\text { group }(\mathbf{n = 3 0})\end{array}$ & $\begin{array}{l}\text { Control } \\
\text { group } \\
(\mathbf{n}=\mathbf{3 0})\end{array}$ & $\begin{array}{l}\mathbf{P} \\
\text { value }\end{array}$ \\
\hline \multicolumn{4}{|c|}{ Endometrial pattern } \\
\hline Normal & $25(83.3 \%)$ & $2790 \%)$ & 0.58 \\
\hline Heterogenic & $2(6.7 \%)$ & $1(3.3 \%)$ & \\
\hline Echogenic & $3(10 \%)$ & $2(6.7 \%)$ & \\
\hline $\begin{array}{l}\text { Endometrial } \\
\text { thickness (mm) }\end{array}$ & $10.2 \pm 1.7$ & $9.7 \pm 1.8$ & 0.62 \\
\hline \multicolumn{4}{|c|}{ Uterine artery Pulsatility Index (PI) } \\
\hline Right & $2.5 \pm 0.6$ & $3.6 \pm 0.3$ & $<0.05$ \\
\hline Left & $2.4 \pm 0.8$ & $3.9 \pm 0.2$ & $<0.05$ \\
\hline \multicolumn{4}{|c|}{ Uterine artery Resistance Index (RI) } \\
\hline Right & $0.66 \pm 0.1$ & $0.9 \pm 0.05$ & $<0.05$ \\
\hline Left & $0.62 \pm 0.2$ & $0.86 \pm 0.08$ & $<0.05$ \\
\hline $\begin{array}{l}\text { Clinical } \\
\text { pregnancy }\end{array}$ & $18(60 \%)$ & $8(26.6 \%)$ & $<0.05$ \\
\hline
\end{tabular}

Heterogenic endometrial pattern was observed in $6.7 \%$ of Sildenafil patients and $3.3 \%$ in the control patients, while echogenic pattern was seen in $10 \%$ of the Sildenafil 
patients and $6.7 \%$ of the control patients. Similarly, endometrial thickness was $10.2 \pm 1.7$ and $9.7 \pm 1.8 \mathrm{~mm}$ in Sildenafil and control group respectively, $\mathrm{p}$ value $=0.62$. Using Doppler ultrasound, uterine artery PI was significantly lower in Sildenafil group patients as compared to control group patients. Similarly, we found uterine artery RI was also significantly lower in the Sildenafil group patients as compared to control group patients. We followed the patients and found that clinical pregnancy rate was significantly higher among Sildenafil group $(60 \%)$ as compared to control group (26.6\%), p value $<0.05$.

\section{DISCUSSION}

In the present study, we found that endometrial thickness and ultrasound pattern were similar in both the study groups. The importance of the endometrial pattern as a predictor of treatment cycle outcome in IVF-treated patients has been studied previously4, as successful implantation depends on the endometrial quality as well. ${ }^{5}$ It has been shown that pregnancy rate improves with increasing endometrial thickness. The results of previous studies have shown that vaginal as well as oral sildenafil citrate, alone or with oestradiol has also been shown to significantly improve endometrial thickness. ${ }^{6}$ In another study, Sher et al reported that vaginal sildenafil (25 mg, 4 times per day) improved endometrial thickness ( $\geq 9 \mathrm{~mm}$ ) in $70 \%$ of the patients. ${ }^{7}$ Fetih et al reported that vaginal gel of sildenafil significantly increased endometrial thickness and uterine blood flow. ${ }^{8}$ The results reported by Chanona et al showed that the use of vaginal sildenafil in patients whose endometrial thickness was equal to or less than $7 \mathrm{~mm}$ in the failed assisted reproductive technology (ART) cycles led to an increase in implantation and pregnancy. ${ }^{9}$ However, successful pregnancy cannot be predictable solely based on endometrial thickness. ${ }^{10}$ The was demonstrated in our study as well. We observed a significantly higher pregnancy rates among patients in the Sildenafil group as compared to control group, without a corresponding increase in endometrial thickness or echogenicity pattern.

We observed that uterine artery PI and RI were significantly lower in patients who received Sildenafil as compared to control group. Similar to our results, Malinova et al found significant decrease in PI and RI of uterine artery in patient group received $25 \mathrm{mg}$ sildenafil citrate. ${ }^{11}$ We also observed that the clinical pregnancy rate was higher in the sildenafil than in the placebo group. This would suggest that higher uterine blood flow is associated with higher implantation and pregnancy rates. This would reiterate the clinical utility of ultrasound in assessing the developmental potential of basal layer of the endometrium. Our results are in contrast to the study by Abdel Kader Fahmy et al, who reported a 2.5-fold increase in pregnancy in the sildenafil group, but this difference was not statistically significant. ${ }^{12}$ Likewise, Kim et al reported that the use of vaginal sildenafil plus oral oestrogen pills in the luteal phase of patients treated with an IVF-ET cycle increased the pregnancy rate by two-fold, but this increase was not statistically significant. ${ }^{13}$

\section{CONCLUSION}

Vaginal sildenafil resulted in significantly higher pregnancy rates in our study population. The uterine artery PI and RI were significantly lower in patients taking Sildenafil. However, endometrial thickness and ultrasound pattern was similar to those in the control group. Considering a low sample size, future clinical trials need to be conducted with vaginal sildenafil on larger numbers of these patients.

\section{Funding: No funding sources}

Conflict of interest: None declared

Ethical approval: The study was approved by the Institutional Ethics Committee

\section{REFERENCES}

1. Singh M, Chaudhry $\mathrm{P}$, Asselin E. Bridging endometrial receptivity and implantation: network of hormones, cytokines, and growth factors. J Endocrinol. 2011;210(1):5-14.

2. Richter KS, Bugge KR, Bromer JG, Levy MJ. Relationship between endometrial thickness and embryo implantation, based on 1,294 cycles of in vitro fertilization with transfer of two blastocyststage embryos. Fertil Steril. 2007;87(1):53-9.

3. Vilchez RB, Cosp XB, Glujovsky D, García VA, Colmenares FM, Zapata MJ. Vasodilators for women undergoing fertility treatment. Cochrane Database Syst Rev. 2018;10.

4. Sher G, Herbert C, Maassarani G, Jacobs MH. Assessment of the late proliferative phase endometrium by ultrasonography in patients undergoing in-vitro fertilization and embryo transfer (IVF/ ET). Hum Reprod. 1991;6(2):232-7.

5. Sher G, Dodge S, Maassarani G, Knutzen V, Zouves C, Feinman M. Management of suboptimal sonographic endometrial patterns in patients undergoing in-vitro fertilization and embryo transfer. Hum Reprod. 1993;8(3):347-9.

6. Paulus WE, Strehler E, Zhang M, Jelinkova L, ElDanasouri I, Sterzik K. Benefit of vaginal sildenafil citrate in assisted reproduction therapy. Fertil Steril. 2002;77(4):846-7.

7. Sher G, Fisch JD. Effect of vaginal sildenafil on the outcome of in vitro fertilization (IVF) after multiple IVF failures attributed to poor endometrial development. Fertil Steril. 2002;78(5):1073-6.

8. Fetih AN, Habib DM, Abdelaal II, Hussein M, Fetih GN, Othman ER. Adding sildenafil vaginal gel to clomiphene citrate in infertile women with prior clomiphene citrate failure due to thin endometrium: a prospective self-controlled clinical trial. Facts Views Vis Obgyn. 2017;9(1):21-7. 
9. Chanona J, Garcia M, Ruvalcaba L, Bermudez A, Muniz M, Beltrian M, et al. The Mexican experience in the use of vaginal sildenafil in patients with poor endometrial response. International Congress Series. 2004;1271:19-21.

10. Kovacs P, Matyas S, Boda K, Kaali SG. The effect of endometrial thickness on IVF/ICSI outcome. Hum Reprod. 2003;18(11):2337-41.

11. Malinova M, Abouyta T, Krasteva M. The effect of vaginal sildenafil citrate on uterine blood flow and endometrium in the infertile women. Akush Ginekol (Sofiia). 2013;52(1):26-30.

12. Fahmy A, ElSokkary M, Sayed S. The value of oral sildenafil in the treatment of female infertility: a randomized clinical trial. Life Sci J. 2015;12(4):7882.

13. Kim KR, Lee HS, Ryu HE, Park CY, Min SH, Park $\mathrm{C}$, et al. Efficacy of luteal supplementation of vaginal sildenafil and oral estrogen on pregnancy rate following IVF-ET in women with a history of thin endometria: a pilot study. J Wowens Med. 2010;3(4):155-8.

Cite this article as: Kapoor A, Sharma G, Bakshi R. Outcome of vaginal sildinafil in assisted reproductive technology cycles. Int J Reprod Contracept Obstet Gynecol 2021;10:575-8. 